\title{
Medical Humanism in the Making: Symphorien Champier (1471-1539) and Galen
}

L'invention de l'humanisme médical : Symphorien Champier (1471-1539) et Galien

\section{Caroline Petit}

\section{(2) OpenEdition}

\section{Journals}

Édition électronique

URL : https://journals.openedition.org/aes/3753

DOI : 10.4000/aes.3753

ISSN : 2258-093X

Éditeur

Laboratoire LISAA

Référence électronique

Caroline Petit, « Medical Humanism in the Making: Symphorien Champier (1471-1539) and Galen », Arts et Savoirs [En ligne], 15 | 2021, mis en ligne le 25 juin 2021, consulté le 17 décembre 2021. URL http://journals.openedition.org/aes/3753 ; DOI : https://doi.org/10.4000/aes.3753

Ce document a été généré automatiquement le 17 décembre 2021.

Centre de recherche LISAA (Littératures SAvoirs et Arts) 


\section{Medical Humanism in the Making: Symphorien Champier (1471-1539) and Galen}

L'invention de l'humanisme médical : Symphorien Champier (1471-1539) et Galien

Caroline Petit

I am grateful to the anonymous reviewers of the journal for their pertinent remarks. In addition, I was fortunate enough to benefit from the insights of various audiences along the road, especially at the Renaissance Society of America's annual meetings in 2018 and 2019; at research seminars in Oxford and at Johns Hopkins University in 2017; and at the annual meeting of the Society of Italian Studies in Hull (2017). This work is based on research undertaken in the collections of the Wellcome Library and the British Library in London, the Bibliothèque Mazarine and the Bibliothèque de l'Académie de Médecine in Paris, and the Osler Library in Montreal. The Centre for the Study of the Renaissance at the University of Warwick helped fund my travel and my research, notably through awarding me a grant from the Greg Wells Fund. The Osler Library awarded me a Bensley travel grant. I dedicate this study to the late Paola Tomè, whose warm encouragements enabled me to pursue my investigations on Symphorien Champier, and whose dedication to research remains an example for us all.

1 A major proponent of ancient medicine in early humanist France was Symphorien Champier. He wrote numerous medical works in which he engaged with many ancient and medieval texts. Although not a translator himself, Champier played a passeur's role, diffusing ancient medical ideas and texts widely through his popular writings. Active in the first four decades of the sixteenth century, Champier witnessed a period of deep transformation in the learned circles of his time; through his many connections in Italy and France, he embodied, in addition, a privileged perspective on the growing intellectual exchanges between both sides of the Alps around 1500. Champier's works, however, were overlooked for a long time: while some facets of his oeuvre have received scholarly attention in the past decades, his dozens of medical works have barely received notice. In the field of French studies, he was eclipsed by his younger 
and more brilliant colleague, Rabelais, even though they shared many interests and tastes - including all things medical. Indeed, it was through his medical output that Champier may have laid some foundations for stars like Rabelais to rise $^{1}$. In this article, I aim to illuminate the remarkable role Champier played in the shaping of medical humanism in Renaissance France, exploring the impact of the "new" Galen upon the trajectory of a humanist like Champier. To this end, I focus on selected medical works by Champier that deal specifically with Galen, namely his Speculum Galeni and Historiales Campi. I will then turn towards his literary output, especially the Bellum Medicinale, in which he displayed a talent for burlesque humour that may have inspired Rabelais.

\section{Transitioning to Medical Humanism: the Case of Symphorien Champier}

\section{A scholastic scholar}

Champier's career was anything but ordinary. Although we know relatively little about his formative years, we do know that he flourished from about 1490 to 1539, straddling two major centres of humanism (Northern Italy and France). His work coincided with two of the most important centuries in the dramatic transformations in the field of medicine. I do not mean specifically scientific discoveries here (Champier died before the publication of Vesalius' work in 1543, for instance), but instead the increased diffusion and understanding of ancient medical works and their impact on learned conversations, among physicians and beyond, through translations and print.

3 A relatively recent discovery has led to a slight reappraisal of the extension of Champier's literary activity. It was long assumed that his first published text was the Janua logice, an introduction to logic firmly rooted in the humanists' approach, and dated to 1498. But a previously undocumented work, Isagoge Simphoriani Champerii in grammaticam disciplinam \& logicam, has resurfaced ${ }^{2}$. Clearly authored by Champier, the copy does not have a print date, but has tentatively been dated to $c .1490$, when Champier was a young teacher ${ }^{3}$. The unicum, now preserved in the Osler Library at McGill University, Montreal, provides us with a puzzling but fascinating document on Champier's intellectual development ${ }^{4}$. In contrast to his previously identified writings, the Isagoge turns out to be a more scholastic work, drawing heavily on Ockham and reflecting the teaching of a more juvenile Champier - the book seems aimed at young students. At this point in Champier's career and intellectual life, medicine seems irrelevant. In retrospect, however, this work is highly significant as a testimony to his early work and education: put in perspective, it shows a spectacular arc of learning, from the scholastic endeavours of his youth to the waves of new translations and new debates in medicine that would accompany his later years. It also illustrates the efforts Champier went to in order to keep pace with the scholarly world of his time, from the late fifteenth century to the late 1530s. The way Champier managed this crucial turn demands respect, and deserves attention. It is worth noting at this point that the newly found starting point of his literary activity (the publication of his Isagoge) more or less coincides with the first printed edition of Galen's complete works, published in Venice in 1490 by Diomedes Bonardus. This publication, although he probably did not know it at the time, was to have a profound influence on his work. 


\section{Medicine and Literature in Lyon}

4 As is well documented, Champier's literary and public career took off in Lyon at the beginning of the sixteenth century. By then, Champier had indeed met Jacques Lefèvre d'Etaples in Paris and become part of the diffusion of Platonism in early Renaissance France. He studied medicine in Montpellier (but also in Northern Italy, where he made many connections), and began writing about the subject, gleaning quotations from newly published ancient texts, for an audience of medical colleagues. Such is the pattern in his early medical works, for example De medicinae claris scriptoribus, which was printed alongside Alessandro Benedetti's Aphorismi in 1506. Those works, to an extent, mark Champier's entrance in the world of the physicians-humanists of this time, as his works are accompanied by prefaces and introductory epistles penned by prominent physicians of the time, including Benedetti himself, as well as Gonsalvo de Toledo, physician to Anne de Bretagne. Those texts mix praise for Champier with humanist manifestos ${ }^{5}$.

5 Champier continued publishing minor medical works well into the next decade. In fact, as late as his 1532 work, Historiales campi (discussed below), he indicated that he felt encouraged to continue with this type of publication, owing to the success of previous works like the De medicinae claris scriptoribus mentioned above. Champier became truly famous in Lyon, however, thanks to a different book, written in French and not in Latin (although there are copious, serious marginalia in Latin): La nef des dames vertueuses (1503), which won him an enthusiastic female readership beyond his usual audience. The slightly provocative undertones of the book, which deliberately moved away from stigmatising famous women of the past, certainly was a factor (as was the clever move to write in French, adding discrete yet significant annotations in Latin, aimed at his male, educated readership); another, I would argue, was the strong medical and natural-philosophical knowledge upon which it is based, especially in book $\mathrm{II}^{6}$. Other aspects of literature, especially historiography, interested him and contributed to his fame as he established the myth of Chevalier de Bayard's heroism - a enterprise that was aided by his marriage to Bayard's cousin, Marguerite.

6 A prominent public character in Lyon, Champier was a polymath and polygraph. It is thus all too easy to forget the many titles he published in the field of medicine. Champier, however took his role as a vernaculariser fairly seriously, and engaged in several debates in the field of medicine ${ }^{7}$.

\section{Arabists and Hellenists}

7 An interesting example of Champier's participation in the debates that agitated medical humanists was the role to be played by Arabic medicine in contemporary training and practice. For centuries, and in Champier's own medical education, the works of Avicenna and other Islamic physicians had played a central role in the training of physicians. As Nancy Siraisi has shown, university set texts changed rather slowly through a whole century of Renaissance discoveries and innovation, and Avicenna retained a place of choice in medical education ${ }^{8}$. Yet discussions, correspondence, and publications tell a different story, highlighting growing interest in the works of Greek and Latin classics, comparing them with the Islamic legacy, and more often than not taking sides in favour of the Greeks. Such was the case of Champier9. 
In the wake of a well-documented controversy started by Niccolò Leoniceno over the value of Pliny the Elder's testimony in scientific matters, and turning his back on his own education, Champier fiercely advocated the superior value of Greek texts over Arabic ones, brandishing typically humanistic arguments, such as the possibility to edit texts through manuscripts and thus reach a better understanding of the original ${ }^{10}$. The debate lasted beyond 1530: Champier's most forceful text on the subject is a letter published in 1533, and he had made allusions to his views in the commentary sections of his Historiales campi in 1532 (see below). His case was based on the genuine belief in the benefit of reading Galen in the original - a possibility that was growing at the time, as new Latin translations appeared regularly, based on the Aldine. Galen, it seems, was a catalyst of Champier's own evolution, as a physician and as a humanist. Was Champier trying to be the French Manardi - one of the Ferrarese medical scholars who influenced him most?

\section{A populariser of Galen}

9 Through his abundant early production, Champier devised new ways of diffusing medical knowledge. In addition to the texts of Aristotle pertaining to medicine, he was also interested in all the great physicians of the past that he could lay his hands on: Hippocrates, whose texts were sometimes printed alongside his own works; and Mesue, of whom he penned a biography that was reprinted throughout the sixteenth century. But he had a special relationship with Galen, who was more than a medical authority to him. Champier seems to have embarked on a mission to make Galen more accessible to his fellow physicians and a broader, educated audience, and Galen, in turn, seems to have provided him with a literary and philosophical role model.

10 As stated above, the 1490 edition of Galen's so-called complete works had a deep impact on Champier's knowledge of the Pergamene's works, although this may not be his only source. Champier then set out to produce digests of Galen of various shapes and length. For a quarter of a century, from the moment Champier started writing Galen-inspired works to the publication of the Aldine of Galen (a game changer) in 1525, the 1490 edition and its subsequent avatars (including that by Surianus published in 1502) remained the reference tool for physicians and other humanists interested in Galen. ${ }^{11}$ The history of early editions of Galen up to 1533 has been refined by Stefania Fortuna, who has carefully dissected their contents, noting the rise of humanist translations in subsequent editions, from 1502 to 1528. Interestingly, she has identified a previously unnoticed edition, curated by a certain Joannes Nebriensis Rivirius and published in Lyon in $1528^{12}$. That edition is an additional, and very intriguing, testimony to Champier's activity in Lyon, as it undeniably reflects his influence as a mentor for younger physicians and as an inspiration for editorial activity around Galen. It ought to be stressed here, for the reader not familiar with the early history of Galen in print, that the 1490 edition (and a large proportion of the editions published in its wake until 1528) was based on medieval translations, some made from Arabic models, some from the Greek (and some, hybrids of both, as in the case of the treatise On simple drugs) ${ }^{13}$. About a quarter of the works included in the two volumes are spurious. The quality of the Latin, owing to the origin of the translations, left much to be desired. Yet for decades, this was the main instrument in the rediscovery of Galen. The Surianus edition (1502), however, had an impact on contemporary medical activity ${ }^{14}$, and much more 
research remains to be undertaken on the links between early editions of Galen and their readers. ${ }^{15}$ In the case of Champier, it would be useful to conduct extensive comparisons between his quotations of Galen and the various early editions of Galen available at the time, although given the sheer number of works published by Champier citing Galen at length, this would be an extensive job. In any case, following the decent success of his early publications on the works of ancient doctors, Champier set out to produce more systematic books on his hero.

\section{Speculum Galeni}

11 The Speculum Galeni ("Mirror of Galen") was, it is thought, published in 1517, when Champier's popularity was already well established. According to Allut, it is relatively widely available in libraries, which suggests it was popular. ${ }^{16}$ The date of 1517 is not entirely secure; the Osler catalogue suggests that their copy (shelfmark 2268) is a reprint, and the original publication took place in 1512. Interestingly, the catalogue of the Bibliothèque de l'Académie de Médecine concurs, but upon examination, the date of 1512 was added by hand in the copy of the Académie, formerly Daremberg's possession (shelfmark D3028). The date commonly in use is thus to be treated with caution. A possible explanation for this debate lies in the controversy chronicled in the letters accompanying the text, and duly reported by Allut: a first printing of the book seems to have fallen into the hands of an anonymous foe, who stole and defaced the books ${ }^{17}$. This controversy apparently led to a second, revised printing -possibly our 1517 copies, for no copies of 1512 seem to survive.

In any case, this publication followed a number of previous opuscules aimed at physicians. In the same decade, Champier also published summaries of Galen's commentaries to Hippocrates, long before the better-known work of Andres de Laguna ${ }^{18}$. He also published an intriguing essay that sought to reconcile the views of Plato, Aristotle, Hippocrates, and Galen ${ }^{19}$. The latter includes a tantalising illustration, showing Galen engaging in a violin quartette (with, presumably, Plato, Hippocrates, and Aristotle). The Osler copy of the Symphonia (shelfmark 2269) also includes two epistles commending the work of Champier by Luigi Marliano and Pierre Picot, respectively (both dated 1513). The 1510s were very productive years for Champier, who also published Practica nova in medicina in 1517, which was a methodical introduction to medicine, starting with a historical account of medicine and including a treatise on fevers ${ }^{20}$. This was reprinted in 1522 in Venice and in 1547 in Basel, testifying to Champier's enduring success across borders.

13 Albeit limited in length, the Speculum Galeni summarised Galen's doctrine, according to four sections, and was based on a variety of treatises read by Champier. It is more ambitious than his previous works: it is more comprehensive, and reflects the author's new ambition to provide useful tools to help read ancient doctors. The Speculum starts with an index of the topics and ends with a table of contents. The book included an unprecedented effort to contextualise Galen's ideas and texts: a preliminary essay (ff. iii) even included a biography of Galen, highlighting his youth and education, his travels (distinguishing between his two navigationes to Rome), and finishing with a general praise for his superiority. Champier also speculated on the time and place of Galen's death, anticipating many a modern effort (an enigma that remains unsolved) ${ }^{21}$. Champier thus proposed the earliest user-friendly guide to Galen, written in a simple, 
lively manner for an audience possibly wider than physicians. The book included various additions aimed at contextualising Galen better in the history of medicine, including a discussion contrasting Galen and Avicenna:

Avicenna res gessit magnas verum mahometice secretis dolis ac fallaciis usus. Et sicut omnes in eo doctrinam laudant, sic et religionem eius detestant. At Galenus in religione semper moderatissimus ... Sic de Galeno ab aliquibus dicitur quod mallem cum eo errare quam cum Avicenna aut Averrohe recte sentire. Nam Galenus grecus unde omne bonum Avicenna arab $[\mathrm{u}] \mathrm{s}$ quod est mater omnium malorum. ${ }^{22}$ Avicenna accomplished much, but as a Mahometan he also used secret tricks and fallacies. And just like all praise in him his doctrine, similarly they detest his religion. But Galen was always extremely moderate in religion ... As a result, some say about Galen: "I would rather be mistaken with him than be right with Avicenna or Averroes". For Galen is a Greek, the source of all good, while Avicenna is an Arab, the matrix of all evil.

In a stark rhetorical contrast, further stressed by asyndeton, Champier makes Galen the champion of Greekness (and all things good), while Avicenna embodies the evil created by the Islamic religion - a strong, if excessive, statement for a physician trained through Avicenna's works more than Galen's. The international political climate, shaped by the menace from the Ottoman Empire, may partly explain this vindictive tone, but Champier's is also a rhetorical statement in line with the discourse of his Italian friends from Ferrara: the quarrel over the respective merits of ancient classical and Islamic sources, which started with Leoniceno's enquiry into Pliny the Elder, continued for decades, and Champier may have had little choice (or desire) to express a dissenting opinion ${ }^{23}$. In fact, Champier is often full of praise elsewhere for Avicenna, the great authority in medicine of his time and later a master in Europe for centuries. By adopting this polemical and slightly provocative tone, Champier means to demonstrate his commitment to the medical side of humanism, as shaped by Italian scholars, and pledge his faith in the Greeks. The role of Galen in Champier's authorial posture is therefore not just medical. He is part of a manifesto.

This impression is further reinforced by a statement on Galen's literary qualities, aiming at including the Pergamne among the great authors and models of the past:

Stylus Galeni ut aiunt quidam medius inter solutam orationem et carmen fluit suauitas et copia tanta ut Alexander Benedictus nostri amantissimus Galenum et intelligendi et dicendi grauissimum auctorem fuisse dixerit atque omnia (ut adiecit) turpi barbarorum colluuie sedarunt. ${ }^{24}$

Galen's style, as some put it, is intermediate between prose and poetry, its sweetness and abundance flow, to the point that our dearest Alessandro Benedetti declared that Galen is an extremely grave author both in thought and in speech, and that, as he added, all was swept away with the torrent of filth of the barbars.

Although neither the identity of "some" (quidam) nor the exact origin of Benedetti's quotation could be pinned down, Champier's purpose here is crystal clear: in the footsteps of his masters, he sought to emphasise Galen's brilliance in style, and thus include him within the scintillating community of the great classical authors. Such praise for Galen's suavitas and copia may have come out of fashion, but to Champier's eyes (and, I presume, his audience) this statement was unproblematic and rather consensual ${ }^{25}$. In the context of early sixteenth-century France, however, this is a powerful declaration of humanist intentions. Welcoming Galen among the founders of European culture, through his style and elevation, was an important shift from the usual view of Galen as a master of medicine, an authority in technical matters. It put Galen on the same level as Cicero or Pliny. This would not only remain a line of thought 
throughout Champier's work, but would also have a tremendous influence on his own writing and inspire (albeit indirectly) medical authors of the new era $^{26}$. It would also contribute to the wider appreciation of Galen among the educated, beyond his primarily medical readership. Champier's immediate success with this and previous works is proved by the editor of medical works Pietro Antonio Rustico, who celebrated Champier as an especially enlightened and tireless promoter of new translations and of Galenic studies ${ }^{27}$.

\section{Historiales Campi}

17 The last decade of Champier's life and career, as Richard Cooper has observed, coincided with a flourishing of new Galen translations, and benefited from an increased quality in book printing. ${ }^{28}$ In an incredibly prolific period, he produced inter alia a work that is seldom mentioned and was long assumed to be a ghost work, because the author of the main bibliography of Champier, Allut, could not find a copy of $\mathrm{it}^{29}$. The Historiales campi, a large-format work published in Basel with Cratander, is a much-improved attempt at diffusing Galen through selected pieces, with a commentary ${ }^{30}$. The work consists of four books of uneven length, containing respectively 42, 20, 21, and 25 stories by Galen (108 altogether) and the author's discussion of them. In his preface, Champier explains the genesis of this new work:

A plerisque saepe rogatus sum, ut Galeni historiales campos, quos sane multos hactenus sparsim scripsi, in unum colligerem, \& officiosa impressorum manu atque industria ea omnia ante recognita, accurateque digesta, communia pluribus redderem. Negocium meum aliquando cogitans haesi, distuli, torsique me etiam; ea enim erant partim ita dispersa, ut receptui classico nullo quidem signo ad vexilla revocari amplius facile possent. Partim etiam in discipulorum manibus habebantur per Galliae totius diversa gymnasia, partim caecis nostrae bibliothecae angulis, situ ac pulvere pene tabescentia diu jacuerant, procul a mente, omnique memoria; ut difficilimum sane mihi videretur, in corpus aliquod unum tot membra disiecta componere. Meas cogitationes quoque, non magno studio lucubratas, satis placere posse diffidebam, iis praesertim, qui stricta libella omnia appendunt, \& corrugata fronte ac rhinoceroteo naso aliena tanquam odorant.

Many begged me to collect into one volume the historiales campi of Galen ${ }^{31}-\mathrm{I}$ had written quite a few, scattered in my writings; to collate and order properly all those already identified by the diligent hand and care of printers, and to make them widely available. Thinking about my task sometimes, I hesitated, delayed, agonised even; for they were in part so scattered that they were difficult to recover, in the absence of a war trumpet to recall the troops. Part of them were in the hands of students, spread all over the schools of France; part lay in the dark corners of our library, rotting in mold and dust, unheeded and forgotten; hence it seemed extremely difficult to me, to gather so many membra disjecta into a single volume. Moreover, I doubted my unstudied, idle thoughts had sufficient appeal, especially towards those who weigh up every book that comes out, and sniff out, so to speak, those they do not like, with the wrinkled face and nose of a rhinoceros.

18 An entertaining prose writer, Champier exaggerated the challenge of gathering the scraps of his writings dedicated to Galen, and of producing a decent enough book to placate the censors, who are portrayed as ugly, hostile animals in a striking image. His agony over publishing this book thus comes across as only half-serious. But Champier goes on, explaining the pivotal role of De claris medicis scriptoribus in his rising fame:

Atque ideo interim coepi lucem emittere De claris medicis librum, praetentaturum iter, qui impressoria arte diffusus in plurimos, a multis probatus, atque ut ipse vidi 
digne habitus est; cui clarum praeter caeteros testimonium dedit Alexander Benedictus ille noster: ille inquam, qui singulari doctrina, \& accurata de re quaque ratione graecarum praeterea litterarum eruditione, aetatis \& seculi nostri nemini cedit; ea una epistola ad nos in Galliuam, quae ad philosophiae Platonicae caput apposita, veluti serenissima gemma fulget et emicat. Hinc incensa mihi fiducia, ut caeterea ista quae diximus ita sparsa quoquoversum ac disseminata, in unum cogeremus. Quod cum fecerimus, quae ex multis deperditis inventa receptaque sunt (quae sane Galeni historiales, a Campegiorum cognomine Campos appellandas duximus) tuo amplissimo nomini merito dedicanda putavimus. Fruere igitur, \& et me vicissim ama.

Meanwhile, I published my book De claris medicis, the start of a journey ahead, which was widely diffused in print, was approved by many, and, as I could see myself, considered a worthy book; for our dear Alessandro Benedetti wrote a testimony better than all the others: yes, he who is second to none in this day and age in terms of originality of thought, and perfect knowledge of ancient Greek literature; in one letter he sent to France, which is at the head of Platonic philosophy and sparkles and shines like a pure gemstone. Thus was my confidence boosted enough to make me gather into a book all the scraps I mentioned, all scattered about. Once this was done, we thought it was fair to dedicate to your glorious name the fragments of many lost works thus discovered and assembled (which I decided to call the historiales campi of Galen, from the name of Campeggio).

19 Champier's long-standing (and partially imagined) connection with the Italian Campeggi reappears here to explain in part the title of the book, historiales campi Galeni, in which the "fields" (campi) echo the Latin form of his own chosen patronym (campegius). This apparent merging of Galen's texts with his own self is by no means insignificant: in fact, Champier's preface is essentially about himself and his own project, rather than a justification for his choice of author. He focused more on his past works, which he painstakingly reassembled to produce a new book, and on his 'ideas' (cogitationes), which appear here in the form of comments, or a commentary, to Galen himself. The alleged starting point of this book - a request from friends - is a wellknown topos; indeed, it is an especially strong trope in Galen's works, who himself often claimed to write at the request of his friends (as in his famous De methodo medendi, for example). Here, prefatory rhetoric combined with the deeply 'Galenic' persona that Champier was creating - a persona perhaps responsible for the irritation that still arises among those who read Champier (as with those who read Galen). More important perhaps, at least to Champier's eyes, is the strong support offered by a prominent medical humanist from across the Alps, Alessandro Benedetti. Italian recognition was, in Champier's time, in the first few decades of the sixteenth century, a crucial factor in establishing his legitimacy as a medical author and a humanist. Benedetti's praise was the trigger Champier needed to find the willpower to bring his project to completion ${ }^{32}$.

In contrast to earlier pieces he dedicated to Galen, and medicine generally, the Historiales campi displayed a strong, authorial voice on Champier's part. The term commentarius, found at the outset of book 1, is central: In Claudii Galeni Pergameni Historiales Campos, D. Symphoriani Campegii, Equitis Aurati et Medici Clarissimi, commentariorum liber primus (f. 1r). Champier alternated between stories by Galen (usually closed by a sic scriptum est apud Galenum) and comments of his own - many of which digress away from the point expressed by Galen. The form (text and comments) and the structure in four books are not innovative: they echo many medieval works, and as a style seemed to be prized by Champier himself (the Nef des dames vertueuses, for instance, is also in four parts). The comments section, however, is as much a space of 
explanatory discourse (as opposed to the narratives selected from Galen) as a tribune for Champier, who does not lose sight of the questions that agitated the debates of his time. Champier thus managed to create a lively, and highly rhetorical, text out of this blend of ancient texts and traditional form.

Another important feature of the book ought to be noticed from the outset: the focus on narratives. The Galenic passages that Champier assembled are, for the most part, stories: not just case histories, as some would expect, but colourful narratives taken from a variety of works. As we have seen, Champier was quite fascinated with Galen's life (he wrote the first Western biography of the Pergamene). With this anthology, he was creating a convenient repository of Galenic passages of potential interest to a wide array of humanist readers, well beyond the obvious circle of physicians. This anthology was all the more appealing to a reader of the 1530s because it is drew upon a widened range of sources. In contrast to the limitations imposed on the Speculum Galeni by the scarcity of Galenic texts available in print at the time, Champier's new book drew upon new Latin translations published in the wake of the Aldine edition of 1525 . He was therefore offering a more readable Galen.

Let us now turn to some of the more striking themes of Champier's discussions in the Historiales campi. In such a long book, Champier discussed many a medical topic, and broached several areas of the medical art, from diagnostic to therapeutics, including pharmacology and surgery. In his commentary, he sometimes discussed issues that were of interest to physicians of his time; his commentary reflected conversations had with named fellow physicians, such as Jean Galfred and Hippolyte Dantreppe about head wounds ${ }^{33}$. Quite significantly, this discussion was staged in the commentary to the last Galen story, at the end of book IV, thus closing the work. Comparing ancient texts and modern ideas, and alluding to several translations of the ancient works mentioned, this commentary in many respects encapsulated medical humanism as conceived by Champier: a lively, productive conversation on medicine, duly rooted in Greek and Latin reference texts.

Throughout the Historiales campi, Champier touched on themes his readers had grown accustomed to - the role of Greeks versus Arabs, occultism (blending alchemical and medical references), Catholic morality and, in connection with the latter, sexual health. Even if some of his ideas had shifted or taken a more radical turn, Champier managed to give a fresh (or at least entertaining) perspective on them through his lively, often passionate style. In his vehement case against masturbation, he discussed a famous story about Diogenes, in which Galen approved of the philosopher's healthy purging of semen. Champier allowed himself to castigate Galen's non-Christian views and anchored his own diatribe in St Paul's epistles - in a manner reminiscent of many a passage in the Nef des dames vertueuses and other earlier works. In addition to his colourful style, Champier's constant overstepping of literary boundaries makes the reading of the Historiales campi especially entertaining.

\section{From medicine to literature?}

Champier's background as a physician, and his deep interest in both the rapidly rising and expanding field of "medical philology" and the medical controversies of his time, carried over into his more literary writings. Categorising some of his works as "literary" is not entirely satisfactory of course, just as burying his many works on 
medicine as 'technical' is also unhelpful. Champier's works show the rather porous boundaries between the 'literary' and the "technical", and lend themselves to playful interaction. Whilst very aware of genre rules and expectations (he grounded his works in recognisable formats, such as the speculum or mirror, the commentary, the letter, and so on), Champier was able to add a "medical" undertone to any text ${ }^{34}$. His most famous work, the Nef des dames vertueuses, published in 1503, contains medically inspired advice ${ }^{35}$. A popular topic in epideictic rhetoric, the praise and blame of women gave him an opportunity to appear both provocative (refusing to blame famous heroines) and able to deliver sound, nature-based advice (displaying his medical training), especially in book 2 (about marriage). The women-friendly book, written in French and therefore accessible to a wider female readership, also pleased the male educated audience, who could read the Latin marginalia in addition to the French text. The gender problem at play, combined with the success of the book and the double layers of discourse in French and Latin, have made this particular work by far the best known and most studied text by Champier ${ }^{36}$. It certainly fits within a broader understanding of 'medical humanism' as integrating medical thought with topics of common philosophical, natural, and social interest. Champier managed to somehow "medicalise" the hottest topics of his time - his success can thus be interpreted as proof of the timeliness and relative originality of his approach. While similar writings on women continued being published in the next decades, Champier was not alone in writing on such topics in the early sixteenth century; his exact contemporary Jean d'Ivry (born 1472), although better known for his translation of Vergil (1509), happened to write also a scrinium medicine and a book on the secrets of marriage ${ }^{37}$.

Later on, as the Nef was reprinted (1515) and several other opuscules, philosophical and medical - some of which discussed above - were published, Champier apparently reached the peak of his success. Among the texts from this period that deserve further study and appreciation from the perspective of the French Renaissance literary history is his Bellum medicinale. A burlesque piece, the Bellum Medicinale narrates an internecine war within the body between the various organs in order to decide whether the heart or the brain ought to rule: a battle that was a thinly veiled metaphor for the controversy between Aristotle and Galen ${ }^{38}$. In spite of its form and the extremely truculent humour he dared to indulge in, Champier saw this short work as at least partially serious, since he referred the reader to it in the Lunectes des Chirurgiens, published in 1532. Champier began with a preliminary chapter about the beauty and singularity of man in Creation, citing many ancient authorities - notably Cicero - and praising the mind of man as the hallmark of his superiority. This Aristotelian-Galenic preamble is bound to deceive the reader, for the author's real focus is the body and its internal workings, as will soon become clear ${ }^{39}$. Imitating epic tales of failed embassies and negotiations, body parts are soon marching to war, in a deluge of corporeal accidents that culminate with a blockade by the anus. The heroism of fierce Mentula (for Champier chose a male body) will remain meaningless: the effects of the blockage are such (and best not printed here) that all parties cease fire and the war ends. Champier thus produced a virtuoso piece of narrative with a medical theme. Although written in prose, the piece clearly made fun of epic writing - Mentula is a new Achilles, and so on. Body parts and waste products are exploited to hilarious effects. This vein of burlesque in French literature is best epitomised by Rabelais; given the well-known spiteful reference to Champier's De clysteribus (another opuscule) in Rabelais's 
Gargantua, one may wonder if this work, too, could have inspired Rabelais, perhaps in a more productive way ${ }^{40}$.

\section{Conclusion} along several lines: the reception of ancient medicine in a broad sense; the integration of medical, philosophical, and rhetorical writing; and the exploitation of medical themes for entertainment and the diffusion of medical knowledge. In a way, the beautiful illustration (see below) of the Symphonia Galeni etc published by Champier in 1516, which depicts a musical Galen engaging in a string quartet with Hippocrates, Plato, and Aristotle among some trees, encapsulates many aspects of medical humanism: the attempt to reconcile the teachings of philosophy and medicine, to harmonise the doctrines of Plato and Aristotle, and of Hippocrates and Galen; and the faith in a certain harmony of knowledge and thought coming from Greco-Roman antiquity, in a close proximity and in dialogue with divine nature.

Champier can also be seen as a bridge between Italian and French medical humanism at a crucial time in the history of Renaissance knowledge transfers and literary genres. From imported Italian controversies in the early sixteenth century to the strangely vehement nativist stances of his later years, from borrowing from, and praising, his Italian counterparts, to seeing his own works reprinted in Italy, Champier never ceased interacting with transalpine medical humanism. His enduring friendship with Manardi, in particular, fuelled his own medical thought. Through his summaries, compilations, anthologies, and various other efforts of populariser of ancient medical knowledge, both in Latin and in French, he acted as a true humanist passeur, increasing and improving the volume of knowledge available to a relatively wide audience in Lyon and Paris. As we have seen, his influence translated in very concrete terms, too, inspiring a student of his to produce his own edition of Galen in 1528. His notoriety, partly due to his non-medical production (such as the life of Bayard), and owing to his standing as a public figure in Lyon, certainly helped with this life-long engagement with medical humanist endeavours. Yet, so did his multiform talent and satiric verve.

Some shadows and questions remain: the actual impact of Champier's work beyond his death is little studied, as is his possible role in Rabelais' inspiration (beyond the famous rabelaisian allusion to his work on clysters). The impact of Champier's works between the 1500s and 1520s may have faded after the Aldine editions of Galen and Hippocrates were published (1525 and 1526 respectively), owing to a wave of new translations that made older (largely medieval) material slowly fade into irrelevance. Champier himself persisted in reinventing his work, both in terms of format and contents, by updating his material as new translations appeared. This effort may have been short-lived in some areas. But some of Champier's texts were still being reprinted towards the end of the sixteenth century, notably his biography of Mesue; in the area of occulticism, too, Champier remained a point of reference as late as the seventeenth century. A full study of the diffusion of his works remains to be undertaken, and even Allut's reference biobibliographical study is in dire need of updating. 
Osler Library 2269

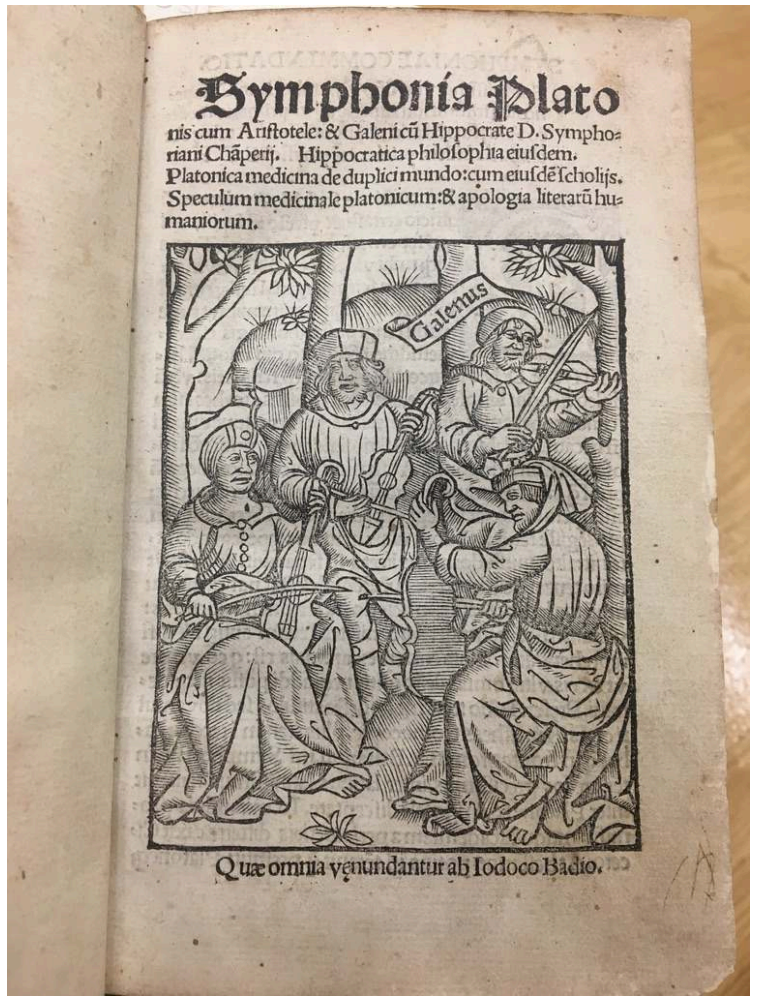

(C) Caroline Petit

\section{NOTES}

1. On the strong impression Champier allegedly made upon Rabelais, see already Alain Boucher, «Les années médicales lyonnaises de Rabelais », Histoire des sciences médicales, vol. XXVI, n³, 1992, p. 197-206 ; Id. «L'héritage lyonnais d'Hippocrate », Histoire des sciences médicales, vol. XXIX, $\mathrm{n}^{\circ} 3,1995$, p. 219-226.

2. Isagoge Simphoriani Champerii in grammaticam disciplinam \& logicam cum denotatione realium vanitatum \& elucidatione nominalium veritatum [not dated].

3. Brian Copenhaver. \& Thomas M. Ward, "Notes from a Nominalist in a New Incunabulum by Symphorien Champier", in Alison Frazier \& Patrick Nold (eds), Essays in Renaissance Thought and Letters. In Honour of John Monfasani, Leiden, Brill, 2015, p. 546-604.

4. The Bibliothèque Mazarine, Paris, holds a reprint of the same work (also a unicum), printed in 1512 in Lyon by Pierre Mareschal; see Henri-Louis Baudrier, Bibliographie Lyonnaise XI, Lyon, Auguste Brun, p. 473; Sybille von Gültlingen, Bibliographie des ouvrages imprimés à Lyon au XVI siècle, vol. I, 35, Valentin Koerner, 2015, p. 43; Ferdinand Buisson, Répertoire des ouvrages pédagogiques du XVI siècle, Paris, 1886, p. 150.

5. I have consulted the copy at the Osler Library (Shelfmark 2264), and the one at the Mazarine (29040), which bears marks of reading and annotating. Bound in the same volume, several minor 
Hippocratic works were included, presented as "newly translated" (noviter de greco in latinum traducta).

6. On this work, see Judy Kem, Symphorien Champier. La nef des dames vertueuses, Paris, Honoré Champion, 2007, esp. p. 29-36 ; and now, Id., Pathologies of Love. Medicine and the Woman Question in Early Modern France, University of Nebraska Press, 2019 (chapter III): Kem efficiently revisits the vexed question of Champier's "feminism" in the light of the near-contemporary Nef des Princes. It strikes me that most references in book II are not Galenic - Aristotle and the Arabs are more often quoted than the Pergamene. This is one of the differences with later works by Champier.

7. Brian P. Copenhaver, Symphorien Champier and the Reception of the Occultist Tradition in Renaissance France, The Hague/Paris/New York, Mouton, 1978, p. 67-81.

8. Nancy G. Siraisi, Avicenna in Renaissance Italy. The Canon and Medical Teaching in Italy after 1500, Princeton, Princeton University Pres, 1987; more recently Dag Nikolaus Hasse, Success and Suppression. Arabic Sciences and Philosophy in the Renaissance, Harvard, Harvard University Press, 2016. On the enduring popularity of Mesue in French and Italian medical humanism, see Dorothea Heitsch's study in this volume.

9. Nikolaus Hasse (op. cit., p. 42-45) stresses correctly that, in his earlier production, notably in the De claris scriptoribus, Champier is still full of praise for Arab physicians and philosophers.

10. Niccolò Leoniceno, De Plinii et plurium aliorum medicorum in medicina erroribus, Ferrariae, 1492. This quarrel has understandably attracted much attention and a considerable body of studies. On Pliny the Elder in the Renaissance, see Roger French, "Pliny and Renaissance Medicine", in Roger French \& Frank Greenaway (eds), Science in the Early Roman Empire: Pliny the Elder, his sources and his influence, London, Barnes \& Noble Book, 1986, p. 252-281; and now the rich collection of papers edited by Alfredo Perifano in Pline l'Ancien à la Renaissance. (Special issue of) Archives Internationales d'Histoire des Sciences, vol. LXI, 2011. As Vivian Nutton rightly points out, Leoniceno's case extends beyond Pliny's errors - he argues in favour of a systematic return to Greek sources (Vivian Nutton, "The Rise of Medical Humanism in Ferrara", Renaissance Studies, vol. XI-1, 1997, p. 4. On Leoniceno's biography and intentions, see D. Mugnai Carrara, 'Profilo di Nicolò Leoniceno', Interpres. Rivista di studi quattrocenteschi, vol. II, 1979, p. 169-212.

11. A useful summary is available at Vivian Nutton, John Caius and the Manuscripts of Galen, London, Cambridge University Press, 1987, p. 1-29. Vivian Nutton also emphasises 1490 and 1525 as key dates in our reading of the history of medical humanism: "The Rise of Medical Humanism: Ferrara, 1464-1555", Renaissance Studies, vol. XI-1, 1997, p. 1-2; as did Walter Pagel, "Medical humanism: a historical necessity in the era of the Renaissance", in Francis Maddison, Margaret Pelling \& Charles Webster (eds), Essays on the Life and Work of Thomas Linacre, c. 1460-1524, Oxford, Oxford University Press, 1977, p. 375-386.

12. Stefania Fortuna, "Galeno latino, 1490-1533"', Medicina nei Secoli - arte e scienza, vol. XVII-2, 2005, p. 469-505. Fortuna stresses that one of the prefatory letters penned by Rivirius is addressed to Antoine Champier, the son of Symphorien, and praises Symphorien Champier for his dedication to Galen. He also refers to Symphorien as his master, one who encouraged him to decicate himself to the study (and editing) of Galen (Fortuna p. 483-483). I did not consult the 1528 edition of Rivirius, which is extremely rare.

13. Vivian Nutton, John Caius, op. cit., p. 26. There is a rich bibliography on Bonardus' edition of 1490 and its sources. On the "hybrid" nature of the Latin translation of Galen's treatise On simple drugs in the Bonardus edition (part Arabo-Latin, part Greco-Latin), see Caroline Petit, "La tradition latine des Simples de Galien. Remarques préliminaires", in Medicina nei Secoli - arte et scienza, vol. XXV-3, 2013, p. 1063-1090.

14. Allen Shotwell, "Alessandro Achillini and the 1502 Galen Opera omnia: the Influence of PseudoGalenic Sources in Early Sixteenth-Century Anatomy", in Caroline Petit, Simon Swain \& KlausDietrich Fischer (eds), Pseudo-Galenica. The Formation of the Galenic Corpus from Antiquity to the Renaissance, London, Warburg Institute, 2021, p. 161-172. 
15. Vivian Nutton, "Books, Printing and Medicine in the Renaissance", Medicina nei Secoli - arte et scienza, vol. XVII-2, 2005, p. 421-442.

16. Paul Allut, Étude biographique et bibliographique sur Symphorien Champier, Lyon, chez Nicolas Scheuring, 1859, p. 195.

17. Ibid., p. 190-194.

18. Epithome commentariorum Galeni in libros Hippocratis, Cohi. Primus Aphorismorum secundus Pronosticorum, tertius Regiminis acutorum morborum, quartus Epidimiarum. Ejusdem ... Centiloquium isagogicum in libros Hippocratis / [Symphorien Champier], 1516 (Lyon, Jean Marion).

19. Symphonia Platonis cum Aristotele; Galeni cum Hippocrate. D. Symphoriani Champerii, 1516 (Paris, Josse Bade).

20. Practica nova in medicina aggregatoris lugdunensis domini Simphoriani Champerii de omnibus morborum generibus ex traditionibus grecorum :latinorum:arabum:penorum ac recentium auctorum: aurei libri quinque. Utem eiusdem aggregatoris liber de omnibus generibus febrium (Lyon, Jean Marion, 1517). I consulted the Osler copy (shelfmark 2273). The Wellcome Library in London has copies of the 1517, 1522 and 1547 editions.

21. For a good overview see the latest biography of Galen by Véronique Boudon, Galien de Pergame. Un médecin grec à Rome, 2012.

22. Speculum Galeni f. iiiv, cap. X.

23. Niccolò Leoniceno, De Plinii et plurium aliorum medicorum in medicina erroribus, op. cit.

24. Speculum Galeni, f. iiv, cap. vI.

25. In agreement with Champier's assessment, see Caroline Petit, Galien de Pergame ou la rhétorique de la Providence, Leiden, Brill, 2018. On the role of rhetoric in humanist translations, see Gastón Javier Basile's remarks in this volume.

26. See the thoughtful remarks of Simone Mucci about Struthius' pose as a new Galen, in his article in this volume.

27. In a letter published at the beginning of the third tome of his complete editions of Galen, together with Champier's Life of Galen. Fortuna, art. cit., p. 480.

28. Richard Cooper, "Les dernières années de Symphorien Champier", Humanisme, Réforme, Renaissance vol. XLVII, 1998, p. 25-50.

29. Paul Allut, op. cit., p. 221.

30. Claudii Galeni Pergameni Historiales Campi, per D. Symphorianum Campegium, Equitem auratum, illustrissimi Lotharingiae Ducis archiatrum, in quatuor libros congesti, \& et commentariis non poenitendis illustrati. D. Symphoriani Campegii, Equitis aurati, Clysteriorum Camporum secundum Galeni mentem libellus utilis \& necessarius. Eiusdem de phlebotomia libri duo. Cum gratia \& privilegio Caesareo ad sexennium. Basileae M. D. XXXII.

31. The "historic fields", which in English does not allow to make Champier's pun with his name really apparent (campi/Campegius).

32. On the medical humanists of Ferrara, especially Manardi, see Daniela Mugnai Carrara, "Nicolo Leoniceno e Giovanni Mainardi: aspetti epistemologici dell'umanesimo medico", in Marco Bertozzi (ed.), Alla corte degli estensi. Filosofia, arte, e cultura nei secoli XV e XVI, Ferrara, Università degli studi, 1994, p.21-40; Id., "Epistemological and methodological problems in Giovanni Manardi's commentary on Galen's Ars parva", in Anthony Grafton \& Nancy. Siraisi (eds), Renaissance Natural Philosophy and the Discipline, Cambridge, MA, MIT Press, 1999, p. 251-274; Vivian Nutton, "The Rise of Medical Humanism: Ferrara, 1464-1555", op. cit., p. 2-19. Alessandro Benedetti was a distinguished Hellenist. Manardi is described by Vivian Nutton as "the first modern Galenist", art. cit., p. 9. Several studies have exlored his humanism, and some focus on his relationship with French humanists such as Champier; see for example Alessandra Preda, "La peste astrologica, ovvero il dibattito sulla 'scienza dei cieli' tra Symphorien Champier e Giovanni Mainardi", in Marco Bertozzi (ed.), op. cit., p. 323-343. 
33. See Symphorien Champier, Historiales campi, IV, 24, and my comments in "Médecine et littérature à la Renaissance" (forthcoming), which offer a more detailed analysis of these conversations.

34. In spite of such recognisable forms, however, it is not always easy to categorise every work quite the opposite. In the case of the Nef des dames, Copenhaver has suggested that Champier blends several genres in one, speaking of "stile a mosaico" (p. 55). See also Judy Kem, 2007, p. 36-37.

35. About which see Judy Kem, Nef des dames, 2007 p. 29-36; Id., Pathologies of Love. Medicine and the Woman Question in Early Modern France, 2019 (chapter III). The Nef des dames vertueuses was printed in 1503, 1515 and 1531, but the original edition is deemed the best (La Nef des dames vertueuses, ed. Judy Kem, Paris, Honoré Champion, 2007, p. 37).

36. See the recent translation by Todd Reeser, Symphorien Champier. The Ship of Virtuous Ladies, Arizona Center for Medieval Studies Press, 2018.

37. On Jean D’Ivry, see Thomas Brückner, «Un traducteur inconnu du seizième siècle: Jean d'Ivry", Les lettres romanes, vol. XLIV, 1990, p.171-180. In a volume preserved in the Wellcome Library (Shelfmark EPB/A/65478) and possibly dated 1519, Jean D'Ivry's Scrinium medicine is bound together with inter alia a large extract from Champier's De corporum animorumque morbis (I, 4-39) under the title De humorum digestione.

38. According to the two copies I examined in the Bibliothèque Mazarine: Medicinale bellum inter Galenum at Aristotelem gestum: quorum hic cordi: ille autem cerebro favebat a domino Simphoriano Champerio compositum in duos libros etc. Lyon, 1516 (?). Another copy is available in the Bibliothèque de l'Académie de Médecine, Paris. In the second copy of the Mazarine (shelfmark 29045), the Bellum medicinale is bound with the Myrouel des Apothicaires and the Lunectes des chirurgiens (1532).

39. Galen's De usu partium was a major anatomical work by Galen, singing the praise of Nature in the spirit of Plato and Aristotle. The rediscovery of this text in the early sixteenth century had a major impact on Renaissance anatomy (notably on Vesalius). Champier quotes from it in his Historiales campi.

40. The reference to De clysteribus was revisited by Jean Dupèbe, "Symphorien Champier et Rabelais: la question des clystères", Bibliothèque d'Humanisme et Renaissance, vol. LXXVI-1, 2014, p. 7-30. Roland Antonioli noted several pastiches of, or allusions to Champier in Rabelais et la médecine, 1976, p. 88 (n. 116) and p. 299 (« De même, quand il [sc. Rabelais] évoque l'agaric ou met au défi les Arabes et les Sabiens de rivaliser avec la graine nationale, c'est l'Hortus Gallicus qu'il pastiche, où Champier prêche la croisade contre les drogues arabes et prône les médecines "bénédictes" qui poussent sur le sol de la Gaule. »)

\section{RÉSUMÉS}

Cet article explore différents aspects de l'humanisme médical à travers la figure du polymathe français Symphorien Champier. Passeur de savoir entre anciens et modernes, entre Italie et France, Champier s'est construit comme savant dans le sillage de la découverte des textes médicaux antiques, notamment Galien. Cet article révèle les liens entre la trajectoire intellectuelle de Champier et la redécouverte de la pensée galénique. 
This article explores various aspects of medical humanism through the figure of French polymath Symphorien Champier. A passeur of knowledge between the ancients and the moderns, as well as between Italy and France, Champier developed as a scholar in the wake of the unearthing of ancient medical works, notably Galen's. This article reveals the interplay between Champier's intellectual trajectory and the redicovery of Galen's thought.

\section{INDEX}

Keywords : Galen, medical humanism, Champier, France, Rabelais, Greek, early editions

Mots-clés : Galien, humanisme médical, Champier, France, Rabelais, Grec, éditions anciennes

\section{AUTEUR}

\section{CAROLINE PETIT}

University of Warwick 